\title{
Stages of Demographic Age in Banat Settlements
}

Bubalo-Zivkovic, . $^{*}$

\begin{abstract}
In demographic analysis of certain regions, municipalities or settlements, it is highly important to analyze changes of sex and age structure of population in those geographic units. Sex and age structure consists of several elements used in the analysis. Large number of those elements is used in defining the stage of demographic age of population within certain geographic units. According to indicators of demographic age of population, seven stages of demographic age were established. The age of population in Banat in the period 1953-2002 shows that the population passes from the stage of demographic maturity to deep demographic old age. In 1953 the settlements in Banat were between early demographic youth and demographic old age. Then in the following fifty years occurred a large shift in demographic age, which resulted in settlements being between demographic old age and the deepest demographic old age in 2002.
\end{abstract}

Key words Demography, population ageing, Banat, settlements
* Milka Bubalo-Zivkovic, University of Novi Sad, Faculty of Natural Sciences, Department of Geography, Tourism and Hotel Managament, Trg Dositeja Obradovića 3, 21000 Novi Sad, Serbia and Montenegro

\section{Introduction}

More concise perceiving of regional differences in the achieved demographic age, as well as more striking observation of changes in age structure of population in the large number of small territorial units ( settlements and municipalities) may be achieved by classification of population into different types of age structure. One of the forms of classification is definition of different stages in demographic age through perceiving several indicators. The classification used in this paper is based on division of stages in demographic age, which was done on the basis of combination of values of five different indicators of the population demographic age: average age, share of population younger than 40 , share of population between 60 and above, and the index of aging as the relation between the share of the old and the share of the young. More indicators were chosen in order to avoid wrong conclusions about demographic age of a certain population in case its age structure was significantly disturbed (Penev, 1995). On the basis of chosen indicators, the total population may be classified according to the achieved demographic age into seven stages which are shown in table 1.

\section{Stages of Demographic Age in Settlements of Banat}

In the period 1953-2002 the population of Vojvodina has switched from the stage threshold of demographic old age to (with certain features of stage of demographic maturity) to the stage of demographic old age $\left(5^{\text {th }}\right.$ stage) which has the characteristic to tend to deep demographic old age. In the same period the population of Banat passed the same stages in the process of aging, from the transitional stages of demographic maturity and threshold of demographic old age to the stage of deep demographic old age. Declining birthrate, i.e. natural growth of the population, and weaker pull factors in the region of Banat caused the population in this geographic unit to become older. In comparison to the stages of demographic age in Serbian southern Province of Kosovo and Metohi$\mathrm{ja}$, it has become evident that the population of Vojvodina is at the edge of entering the deepest demographic old age.

In 1953 the average age of the population in Banat was 30.9 years, and the age index was 0.31 . Young population had the share of $35 \%$ in the total population, middle-aged population had the share of $54.2 \%$, whereas the old had the share of $10.8 \%$. By the year 2002, great changes occurred. Namely, average age of the population increased for nine years and it reached $39.9 \%$, whereas the age index reached the value of 0.97 . The values of these indicators point out to great changes in stages of demographic age in Banat. The share of young population decreased to only $22.5 \%$, whereas middle-aged population retained almost the same share, $55.1 \%$, but the old population had the share of $21.4 \%$, which made more than one fifth of the total population.

Table 1 Stages of demographic age and the criteria of their definition

\begin{tabular}{|l|c|c|c|c|c|}
\hline \multirow{2}{*}{$\begin{array}{l}\text { Stages of } \\
\text { demographic age }\end{array}$} & \multicolumn{5}{|c|}{ Indicators of demographic age of population } \\
\cline { 2 - 6 } & Average age & $\begin{array}{c}\text { Younger } \\
\text { than } \mathbf{2 0} \text { (\%) }\end{array}$ & $\begin{array}{c}\text { Younger } \\
\text { than 40(\%) }\end{array}$ & $\begin{array}{c}\text { Older than } \\
\mathbf{6 0}(\mathbf{\%})\end{array}$ & $\begin{array}{c}\text { Index of } \\
\text { aging }\end{array}$ \\
\hline $\begin{array}{l}\text { 1.Early demographic } \\
\text { youth }\end{array}$ & Up to 20 & 58 and above & 85 and above & Up to 4 & Up to 0,07 \\
\hline $\begin{array}{l}\text { 2. Demographic } \\
\text { youth }\end{array}$ & $20-25$ & $50-58$ & $75-85$ & $4-7$ & $0,07-0,14$ \\
\hline $\begin{array}{l}\text { 3. Demographic } \\
\text { maturity }\end{array}$ & $25-30$ & $40-50$ & $65-75$ & $7-11$ & $0,14-0,28$ \\
\hline $\begin{array}{l}\text { 4. Threshold of } \\
\text { demographic old age }\end{array}$ & $30-35$ & $30-40$ & $58-65$ & $11-15$ & $0,28-0,50$ \\
\hline $\begin{array}{l}\text { 5. Demographic } \\
\text { old age }\end{array}$ & $35-40$ & $24-30$ & $52-58$ & $15-20$ & $0,50-0,83$ \\
\hline $\begin{array}{l}\text { 6. Deep } \\
\text { demographic old age }\end{array}$ & $40-43$ & $20-24$ & $45-52$ & $20-25$ & $0,83-1,25$ \\
\hline $\begin{array}{l}\text { 7. The deepest } \\
\text { demographic old age }\end{array}$ & $43+$ & Up to 20 & Up to 45 & 25 and above & $\begin{array}{c}1,25 \text { and } \\
\text { above }\end{array}$ \\
\hline
\end{tabular}

Source: Penev, G. (1995): Population and households in FR Yugoslavia according to census in 1991, Center of Demographic Research, University of Belgrade, Belgrade 
Table 2 Stages of demographic age in Banat in the period 1953-2002

\begin{tabular}{|c|c|}
\hline Census years & $\begin{array}{c}\text { Stages of } \\
\text { demographic age }\end{array}$ \\
\hline 1953 & $4(3)$ \\
\hline 1961 & 4 \\
\hline 1971 & 4 \\
\hline 1981 & 5 \\
\hline 1991 & 5 \\
\hline 2002 & 6 \\
\hline
\end{tabular}

In Banat, seen on the municipality level in 1953, the population was classified in two stages of demographic age, the third and the fourth stage, i.e. the stages of demographic maturity and threshold of demographic old age, and also between these two stages. Similar situation was recorded in the next census in 1961. But in 1971 faster aging of Banat population was recorded. The main reason was seen in decrease of natural growth of population, especially from 1970s and the beginning of economic crisis in the country. According to that census the largest number of municipalities had population in the fifth stage of demographic age, and significantly less number of municipalities had population in the fourth stage (threshold of demographic old age). The following decade brought slow aging of the population, which classified population of two municipalities (Zitiste and Novi Knezevac) in the stage of deep demographic old age, and one municipality (Pancevo) in the stage threshold of demographic old age. Pancevo had the most favorable demographic position due to the vicinity of the large regional center, Belgrade. According to the census in 1991, the population in the municipalities in Banat was in two stages of demographic age, the fifth and the sixth. The latest census in 2002, recorded the facts that the largest number of municipalities in Banat, even 14, were in deep demographic old age, with the exception of two municipalities, one being in the transitional stage towards demographic old age (Pan- cevo), and the other towards the deepest demographic old age (Plandiste).

General economic situation in the country influences all the municipalities in the way that the population age increases in all the municipalities in Banat. The position of the municipalities causes slower formation of even worse demographic picture in the municipalities. However, large municipalities like Zrenjanin, Pancevo and Kikinda do not attract migrants, and natural population growth is constantly negative or declining and the municipalities pass to the higher stages of demographic age.

If the area of Banat is observed in detail, to the level of settlements, it is obvious that there are also great changes. The largest number of settlements in 1953 was in the stage of threshold of demographic curred. The number of settlements in higher stages of demographic age increased, and the number of settlements in lower stages decreased. The largest number of settlements (92) were in the fourth stage of demographic age. Significant increase was recorded in the number of the settlements whose population was in the fifth stage of demographic age. One settlement reached the stage of deep demographic old age. The settlement Mesic is in the municipality of Vrsac situated in the border region of Banat towards Romania, without good traffic routes to other settlements.

Fast demographic changes which occurred within natural and mechanic changes of the population brought to aging of settlements. Thus in 1971 the largest number of settlements (78) was in

Table 3 Distribution of municipalities according to the stage of demographic age

\begin{tabular}{|c|r|r|r|r|r|r|}
\hline Stage of demographic age & $\mathbf{1 9 5 3}$ & $\mathbf{1 9 6 1}$ & $\mathbf{1 9 7 1}$ & $\mathbf{1 9 8 1}$ & $\mathbf{1 9 9 1}$ & $\mathbf{2 0 0 2}$ \\
\hline 1 & - & - & - & - & - & - \\
\hline $1(2)^{*}$ & - & - & - & - & - & - \\
\hline 2 & - & - & - & - & - & - \\
\hline $2(3)^{*}$ & - & - & - & - & - & - \\
\hline 3 & 4 & 1 & - & - & - & - \\
\hline $3(4)^{*}$ & 3 & 15 & - & - & - & - \\
\hline 4 & 9 & - & 4 & 1 & - & - \\
\hline $4(5)^{*}$ & - & - & 2 & - & - & - \\
\hline 5 & - & - & 10 & 9 & 9 & - \\
\hline $5(6)^{*}$ & - & - & - & 4 & 1 & 1 \\
\hline 6 & - & - & - & 2 & 6 & 14 \\
\hline $6(7)^{*}$ & - & - & - & - & - & 1 \\
\hline 7 & - & - & - & - & - & - \\
\hline
\end{tabular}

Note:*1(2), 2(3), 3(4), 4(5), 5(6), 6(7) - transitional stages in demographic age

old age (74), whereas 34 settlements were in the stage of demographic old age. Significantly less settlements were distributed in other stages of demographic age ranging from the transition between early demographic youth and demographic youth (between the first and the second stage) up to the transition between demographic old age and deep demographic old age (between the fifth and the sixth stage). In the following eight years different changes oc-

Table 4 Distribution of settlements according to stages in demographic age

\begin{tabular}{|c|r|r|r|r|r|r|}
\hline Stage of demographic age & \multicolumn{1}{|c|}{$\mathbf{1 9 5 3}$} & $\mathbf{1 9 6 1}$ & $\mathbf{1 9 7 1}$ & $\mathbf{1 9 8 1}$ & $\mathbf{1 9 9 1}$ & $\mathbf{2 0 0 2}$ \\
\hline 1 & - & - & - & - & - & - \\
\hline $1(2)^{*}$ & 3 & 1 & - & - & - & - \\
\hline 2 & 6 & 5 & 1 & - & - & - \\
\hline $2(3)^{*}$ & 6 & 6 & - & - & - & - \\
\hline 3 & 34 & 18 & 6 & - & - & - \\
\hline $3(4)^{*}$ & 19 & 14 & 5 & 2 & 1 & - \\
\hline 4 & 74 & 92 & 46 & 19 & 2 & - \\
\hline $4(5)^{*}$ & 4 & 9 & 8 & 11 & 4 & - \\
\hline 5 & 18 & 31 & 78 & 66 & 53 & 5 \\
\hline $5(6)^{*}$ & 1 & - & 20 & 20 & 18 & 36 \\
\hline 6 & - & 1 & 12 & 40 & 55 & 80 \\
\hline $6(7)^{*}$ & - & - & 1 & 9 & 18 & 17 \\
\hline 7 & - & - & - & 9 & 25 & 38 \\
\hline Total & $\mathbf{1 6 7}$ & $\mathbf{1 7 7}$ & $\mathbf{1 7 6}$ & $\mathbf{1 7 6}$ & $\mathbf{1 7 6}$ & $\mathbf{1 7 6}$ \\
\hline
\end{tabular}

the stage of demographic old age, 46 settlements were in the stage of threshold of demographic old age, and one settlement in transitional stage to the deepest demographic old age. Demographic changes continued with its fast rate and in 1981 neither settlement was recorded in the first three stages. The largest number of settlements was in the stage of demographic old age, and large number (40) was in the stage of deep demographic old age. Nine settlements were in the transitional stage towards deep demographic old age and the same number in the seventh stage (the deepest demographic old age).

The following decades showed even faster increase in number of settlements which belong to higher stages of demographic age and faster decline of number of settlements in lower stages of demographic age. In 1991, only one settlement was in the transitional stage between the third ant the fourth stage, more than one third of settlements (55) was in the sixth stage and almost the same number (53) in the fifth stage, whereas one seventh of settlements was in the stage of deep demographic old age. The census in 2002 rendered catastrophic results. Neither settlement belonged to the first four stages, 
80 settlements belonged to the sixth stage (deep demographic old age), and 38 was in the seventh stage ( the deepest demographic old age).

\section{Conclusion}

Observing the indicators of the seventh stage of demographic age in Table 1 , we are completely aware that the population of Banat is in rather unfavorable condition and without significant positive changes all the settlements will soon have the population of average age above 40 . The worse sex and age structure of population is observed in settlements of southeast and east municipalities of Banat (Plandiste, Alibunar, Nova Crnja, Zitiste), where also the demographic age is the highest. The population was mainly oriented towards agriculture. However, the worsening position and low income in this industrial branch caused migration of young popu- lation. The prevailing population in those municipalities is mainly middle-aged and older, which raises doubt about survival of the population and settlements in those municipalities in the following decades.

Simple appeal on the present state of the total population in Vojvodina and Banat would not be fruitful unless the deeper crisis, which resulted in the present state of the population in those geographic units, in the country was solved.

\section{References}

1. Penev, G. (1995): Stanovništvo i domaćinstva SR Jugoslavije prema popisu 1991. godine. Savezni zavod za statistiku. Centar za demografska istraživanja, Institut društvenih nauka, Univerzitet u Beogradu, Beograd.

2. Savezni zavod za statistiku, Popis stanovništva 1953. Starost, pismenost $i$ narodnost, knjiga XI, Podaci za opštine prema upravnoj podeli u 1953. godini, Beograd, 1960.

3. Savezni zavod za statistiku, Popis stanovništva 1961. godine, knjiga XI, Pol i starost, rezultati za naselja, SFRJ, Beograd 1965.

4. Savezni zavod za statistiku, Popis stanovništva i stanova 1971. godine, knjiga VIII (drugi deo), rezultati za naselja i opstine, SFRJ, Beograd, 1973.

5. Pokrajinski zavod za statistiku, Popis stanovništva 1981, Stanovništvo prema polu i starosti, Novi Sad, 1983.

6. Savezni zavod za statistiku, Popis stanovništva, domaćinastava i stanova 1991. godine, Elektronsko izdanje popisa, tabela 4, Beograd.

7. Republički zavod za statistiku, Popis stanovnistva, domaćinstava i stanova 2002. godine, Pol i starost, knjiga 2, rezultati po naseljima, februar 2003. Beograd. 